\title{
OMC - A EFETIVIDADE DO SISTEMA DE SOLUÇÃO DE CONTROVÉRSIAS
}

Monografia apresentada como requisito parcial para a obtenção do título de Especialista em Relações Internacionais pela Universidade de Brasília.

UNIVERSIDADE DE BRASÍLIA

ORIENTADOR: PROF ${ }^{\circ}$. DR. CARLOS EDUARDO VIDIGAL

BRASÍLIA 
"É preciso mudar o curso dos acontecimentos. Para isso, é preciso mudar a mente dos homens. Não bastam palavras. Só uma ação imediata voltada para um ponto essencial pode mudar a situação estática atual. É preciso uma ação profunda, real, imediata e dramática que mude as coisas e faça entrar na realidade as esperanças em que os povos estão a ponto de não mais acreditar".

Jean Monnet - Memórias 


\section{RESUMO}

O presente trabalho versa sobre o Sistema de Solução de Controvérsias da Organização Mundial do Comércio - OMC. O grande desafio do referido Sistema consiste na implementação das suas decisões. Por muitas vezes os países conseguem o reconhecimento de que as regras da Organização não estão sendo cumpridas, porém, não há mudança em tais regras, ou seja, o país demandado continua descumprindo as normas do comércio internacional, sem que nada seja feito. Porém, o Entendimento de Solução de Controvérsias da OMC possui atributos que ainda não são ideais para assegurar a plena implantação das decisões, mas funcionam como fortes instrumentos de coerção. O instrumento mais poderoso nesse sentido é a autorização para a Retaliação Cruzada, mas, ainda assim, os países em desenvolvimento não conseguem alcançar o resultado final pretendido, uma vez que não possuem força econômica para aplicação das medidas coercitivas autorizadas pelo Órgão de Solução de Controvérsias. Assim, este trabalho analisará a criação da Organização Mundial do Comércio e seu Entendimento de Solução de Controvérsias, a participação do Brasil nas demandas, com breve análise de dois casos considerados relevantes, e, ainda, as discussões que envolvem a implantação, pelos países em desenvolvimento, das decisões provenientes dos relatórios do painel e do Órgão de Apelação da Organização.

\section{PALAVRAS-CHAVE}

Organização Mundial do Comércio, Sistema de Solução de Controvérsias, implementação, decisão 


\begin{abstract}
This paper describes the WTO's Dispute Settlement System (DSS). The challenge of this system is the implementation of its decisions. Complainant countries can often achieve the recognition that the organization's rules are not being met, however, no changes are being made in such rules, That being said, the respondent country continues to disobey the rules of international trade with no counter measures.

However, the Dispute Setlement Body has attributes that are still not ideal for the full implementation of its decisions, but acts as a strong instrument of coercion. The most powerful tool in this direction is the authorization for cross-retaliation, but even so, developing countries can not achieve the desired result, they do not have economic force for the application of enforcement measures authorized by the DSS. This study will analyze the creation of the WTO and its Dispute Setlement Body, Brazil's participation as a complainant, with a brief analysis of two cases considered relevant and the discussions surrounding the implementation of its decisions by developing countries from the panel and from the Appellate Body of WTO.
\end{abstract}

\title{
KEYWORDS
}

WTO, Dispute Settlement System, implementation, decision 


\section{CAPÍTULO 1}

HISTÓRICO E FUNCIONAMENTO DA ORGANIZAÇÃO MUNDIAL DO COMÉRCIO - OMC

1.1. Do GATT a OMC............................................................................................. 08

1.2 A Organização Mundial Do Comércio - OMC................................................. 11

1.3 O Sistema de Solução de Controvérsias da OMC.............................................. 14

\section{CAPÍTULO 2}

O BRASIL E A ORGANIZAÇÃO MUNDIAL DO COMÉRCIO

2.1. A participação do Brasil na OMC......................................................................19

2.2. O Caso do Algodão ............................................................................................ 22

2.3 O Contencioso do Açúcar ........................................................................................ 26

\section{CAPÍTULO 3}

A IMPLEMENTAÇÃO DAS DECISÕES DO ORGÃO DE SOLUÇÃO DE CONTRÓVERSIAS

3.1. As críticas que envolvem a implementação das decisões emanadas do Órgão de Solução de Controvérsias.

3.2. A Fase de implementação das decisões e recomendações do Órgão de Solução de Controvérsias...............................................................................................31

3.3 Medidas de Compensação e Retaliação - Necessidade de Aprovação pelo Órgão de Solução de Controvérsias......................................................................... 33

3.4 Implementação da recomendação - Caso do açúcar .........................................35

3.5. Implementação da recomendação - Caso do algodão .......................................37

3.6 Do cumprimento das decisões do Órgão de Solução de Controvérsias.......... 39

CONCLUSÃO................................................................................................. 41

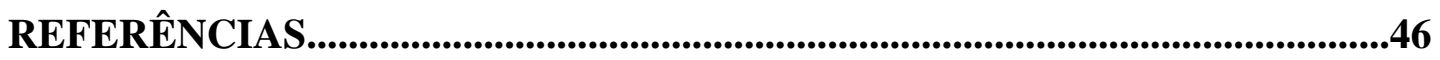




\section{INTRODUÇÃO}

Após o final da $2^{\mathrm{a}}$ guerra mundial, inicia-se a luta pela reconstrução e fortalecimento das relações internacionais, buscando rever os prejuízos gerados com a guerra, e, também restabelecer o equilíbrio e o relacionamento pacífico entre as nações.

Nesse contexto, em encontro histórico ocorrido em Bretton Woods, surge a idéia de uma Organização Internacional do Comércio, onde os aliados assinam acordos na tentativa de reordenar o comércio internacional, e evitar, assim, grandes crises econômicas que possivelmente surgiriam sem a união dos países envolvidos.

Porém, em razão das limitações da época, e da negativa dos Estados Unidos em ratificarem a sua entrada na OIC, a concretização de uma Organização Internacional do Comércio não aconteceu, sendo substituída pela assinatura do GATT, que se caracterizava como um acordo provisório, com a função de estabelecer a regulação das negociações comerciais internacionais.

Em que pese o GATT ter sido responsável pela consolidação de alguns princípios que regem o comércio internacional, sua estrutura não conseguiu se manter, por razões que serão expostas no $1^{\circ}$ capítulo, fato que ensejou a criação da Organização Mundial do Comércio - OMC.

Foi assim que no ano de 1994, na conferência de Marraqueche, 123 (cento e vinte e três) países aderiram ao acordo que criava a Organização Mundial do Comércio - OMC. Diferentemente do GATT, a Organização Mundial do Comércio se constitui, desde o início, como organização internacional, dotada de personalidade jurídica própria, e com regras claras e objetivas para resolução de controvérsias envolvendo o comércio internacional.

Com a criação da OMC foi firmado o Entendimento sobre Solução de Controvérsias, e criado o Órgão de Solução de Controvérsias, responsável pela análise dos contenciosos havidos entre os países membros da OMC.

Como será analisado no $2^{\circ}$ Capítulo, o Brasil é um dos grandes utilizadores do Sistema de Solução de Controvérsias, é considerado um dos países 
em desenvolvimento mais ativos na utilização dos mecanismos do Órgão de Solução de Controvérsias da Organização Mundial do Comércio. Já participou de 25 casos como demandante, 14 casos como demandado e 61 como terceira parte. O capítulo analisará, brevemente, dois casos em que o Brasil foi demandante: o contencioso do Algodão, disputa que tem como demandado os Estados Unidos. O caso é considerado um dos mais importantes já analisados pela OMC; e o contencioso do açúcar, em que a demandada é a Comunidade Europeia.

Os dois casos tratam de subsídios concedidos em contrariedade às normas da Organização e, em ambos, o Órgão de Solução de Controvérsias reconheceu a dita ilegalidade.

No $3^{\circ}$ Capítulo será abordada a questão da implantação dos relatórios dos painéis e do Órgão de Apelação da OMC. A problemática reside no fato de que os países em desenvolvimento não detêm capacidade econômica para retaliar os países desenvolvidos, que acabam por protelar e descumprir as decisões provenientes da OMC.

Dessa maneira, busca-se a analise da efetividade dessas decisões, e pergunta-se: o Sistema de Solução de Controvérsias é eficiente para os países em desenvolvimento? Os países desenvolvidos aceitam as decisões? Há realmente o cumprimento das decisões? 


\section{CAPÍTULO I - HISTÓRICO E FUNCIONAMENTO DA ORGANIZAÇÃO MUNDIAL DO COMÉRCIO - OMC}

\subsection{Do GATT a OMC}

O comércio internacional há muito é objeto de análise pelos estudiosos, especialmente quando o assunto tratado são as Relações Internacionais. A idéia de uma Organização Internacional do Comércio surgiu após a Segunda Guerra Mundial, quando os aliados, após encontro histórico, firmaram os acordos de Bretton Woods, para ordenar o comércio internacional, após a guerra e evitar, assim, grandes crises econômicas que possivelmente surgiriam sem a união dos países envolvidos.

O intuito de cooperação estava presente, ainda mais após a conscientização dos erros cometidos com o encerramento da primeira guerra mundial. A paz após a segunda grande guerra se fazia extremamente necessária, bem como a recuperação do comércio, com o fito de estimular as importações e exportações pelos países envolvidos nos litígios. Para tanto, uma estrutura envolvendo as negociações se fazia necessária, para que fosse evitada a instabilidade das relações.

Assim, em uma fazenda em Bretton Woods, os líderes das grandes nações ocidentais se reuniram com o intuito de estudar as possibilidades de organização do comércio internacional.

Bretton Woods foi o berço dos projetos que criaram o Fundo Monetário Internacional - FMI; o Banco Internacional de Reconstrução e Desenvolvimento - BIRD, hoje conhecido como Banco Mundial e, também, onde nasceu a idéia de criação de uma Organização Internacional do Comércio - OIC. Como Carla Junqueira ${ }^{1}$ explica, a tentativa de criação da OIC, na Conferência ocorrida em Havana, no ano de 1948, foi frustrada pelo próprio Estados Unidos, que não ratificaram a Carta de Havana. Como alternativa a não-criação da Organização Internacional do Comércio, os países interessados celebraram o Acordo Geral Sobre

\footnotetext{
${ }^{1}$ JUNQUEIRA, Carla. O Brasil e o Contencioso na OMC: Tomo II. SãoPaulo: Saraiva, 2009. p. 265
} 
Tarifas e Comércio, o General Agreement on Tariffs and Trade, conhecido como GATT.

O GATT era um acordo provisório, com a função de estabelecer a regulação das negociações comerciais internacionais. Os principais objetivos do GATT eram a regulação das tarifas comerciais impostas à importação, e o tratamento equitativo do comércio internacional. O GATT foi o responsável pela normatização dos princípios basilares que até hoje regem o sistema multilateral do comércio, quais sejam: o princípio da não-discriminação, que se divide na regra da nação mais favorecida e no tratamento nacional; e o princípio da facilitação do comércio entre as nações.

A regra da nação mais favorecida estabelece que vantagens comerciais ofertadas a um Estado se estendem aos demais, não podendo, dessa forma, haver favorecimento de um Estado sem que os demais também se beneficiem. Tal princípio pode ser observado em alguns acordos bilaterais anteriores ao GATT, como por exemplo, o Tratado de Comércio e Navegação, pactuado entre Inglaterra e Portugal, no ano de $1808 .^{2}$

O princípio do tratamento nacional prescreve que nenhum Estado pode impor barreiras a produtos importados, que não a aplicação das tarifas negociadas, ou seja, uma vez importado, o produto não pode sofrer discriminações, devendo ser tratado tal como o produto nacional.

Deve-se registrar, que apesar das intenções de maior regramento do comércio internacional, o GATT não continha regras concretas sobre soluções de controvérsias, em que pese seus artigos XXII e XXIII instituírem um sistema embrionário de solução de controvérsias, através da conciliação e solução diplomática não contenciosa dos problemas havidos.

Segundo Welber Barral ${ }^{3}$ :

De fato, como foro de negociações que era, o GATT 1947 ressaltava a solução diplomática dos conflitos porventura existentes. Desta forma, o Artigo XXII direcionava a parte reclamante a buscar consultas com a outra, em relação a problemas relacionados com o Acordo Geral. O outro

\footnotetext{
${ }^{2}$ BARRAL, Welber. O Comércio Internacional. Belo Horizonte: Del Rey Editora, 2007. p. 31

${ }^{3}$ BARRAL, Welber, organizador. Solução de Controvérsias na Organização Mundial do Comércio. Brasília: Ministério das Relações Exteriores: Fundação Alexandre Gusmão, 2007. p. 17/18.
} 
único artigo sobre a solução de controvérsias, Artigo XXIII, previa a possibilidade de investigações, recomendações ou determinações pelas partes contratantes, que poderiam suspender concessões negociadas entre as mesmas, se as circunstâncias fossem sérias o bastante para justificar tais medidas. $^{4}$

Porém, a grande problemática do sistema de solução de controvérsia adotado pelo GATT, decorria da necessidade de consenso de todos os seus membros, que formavam o Conselho, na instalação do painel, bem como na aprovação do relatório elaborado pelo painel. Assim, com a necessidade de consenso, a própria parte prejudicada pela decisão ou instauração do painel podia obstaculizá-lo, gerando insegurança e culminando na própria insatisfação do sistema adotado. Deve-se levar em conta, que apesar das imperfeições, o GATT foi o único instrumento multilateral regulador do comércio internacional ativo desde o ano de 1948 até o término da Rodada do Uruguai.

Dessa forma, após as demonstrações de insatisfação, na oitava Rodada de Negociações do GATT, a conhecida Rodada do Uruguai, teve como resultado a criação da Organização Mundial do Comércio, que, como grande inovação, trouxe o Entendimento Relativo às Normas e Procedimentos sobre Solução de Controvérsia (ESC), constituindo o ESC, acordo obrigatório para os membros da nova Organização Mundial do Comércio, que adiante será explicado.

Primeiramente cumpre aduzir que a mudança do GATT em OMC representa a transformação estrutural e amadurecimento das relações internacionais do período. Havia alteração das necessidades internacionais, como, por exemplo, a existência de um Sistema de Solução de Controvérsias mais efetivo, capaz de receber e atender as demandas das novas economias que emergiam à época.

Nas palavras do professor Eiiti Sato

A transformação do GATT em OMC significou mais do que a simples troca de uma instituição por outra. Sob essas siglas há todo um conjunto de mudanças que transcende o mundo do comércio envolvendo não

\footnotetext{
${ }^{4}$ BARRAL, Welber, organizador. Solução de Controvérsias na Organização Mundial do Comércio. Brasília: Ministério das Relações Exteriores: Fundação Alexandre Gusmão, 2007. P. 17
} 
apenas o campo da economia internacional, mas também a própria estrutura internacional. ${ }^{5}$

Nesse contexto, a Organização Mundial do Comércio - OMC é formalizada com o intuito de se adaptar às mudanças havidas nas relações internacionais, tendo como um dos seus objetivos, dentre outros, o de estruturar o sistema de solução de controvérsias que envolvem os países membros, criando regras que possam ser cumpridas para, dessa maneira, facilitar e fomentar o comércio internacional. Tal fato permite acomodar as economias emergentes no sistema internacional, permitindo a regulação das suas ações e possibilitando a contestação, por esses países, de irregularidades cometidas pelas chamadas grandes potências.

\subsection{A Organização Mundial Do Comércio - OMC}

Na histórica conferência de Marraqueche, em 1994, que concluiu a Rodada Uruguai, 123 (cento e vinte e três) países aderiram ao acordo que criava a Organização Mundial do Comércio - OMC. Em contrariedade ao GATT, que apesar de possuir algumas atribuições de organização internacional, nunca perdeu o caráter de acordo provisório, a Organização Mundial do Comércio se constitui, desde o início, como organização internacional, dotada de personalidade jurídica própria, e com regras claras e objetivas para resolução de controvérsias envolvendo o comércio internacional.

Como nos lembra Barral ${ }^{6}$, nas negociações da Rodada Uruguai, os Estados Unidos lutaram pela adoção de um acordo obrigatório que regulasse a propriedade intelectual, bem como o comércio de serviços. Tal fato é considerado por alguns como a grande barganha da Rodada Uruguai, facilitadora da adesão dos países desenvolvidos, uma vez que, os Estados Unidos conseguem a regulamentação que almejavam, tendo em vista que os acordos sobre a propriedade intelectual (TRIPS) e sobre serviços (GATS) receberam a devida regulamentação ao passo que o pleito dos países em desenvolvimento, por uma maior regulamentação do Acordo

${ }^{5}$ SATO, Eiiti. De GATT para OMC e a Agenda do Brasil no Comércio Internacional. In: ALTEMANI,Henrique \& LESSA, Antônio Carlos (Orgs.). Relações Internacionais do Brasil: Temas e agendas. Volume 2. São Paulo: Ed. Saraiva, 2006, p.125

${ }^{6}$ BARRAL, Welber. O Comércio Internacional. Belo Horizonte: Del Rey Editora, 2007. p. 35 
sobre têxteis e sobre a Agricultura são lançados para as rodadas futuras da Organização.

Não se pode pensar que a OMC surge para suprir todas as falhas do GATT. A força política dos países desenvolvidos prevalece, como bem se nota quando da adoção do Acordo sobre Propriedade Intelectual, e da protelação da discussão sobre, por exemplo, Agricultura, tópico fundamental da agenda dos países em desenvolvimento, como o Brasil.

Nesse contexto, traz-se à colação importante crítica formulada pelo Ilustre Professor Eiiti Sato:

Ao menos por ora, não parece haver razões para se supor que, no curto prazo, essa ambigüidade do regime internacional de comércio possa vir a ser eliminada. Aparentemente, a própria natureza da OMC é, por si, ambígua. De um lado, construiu um sistema de solução de controvérsias bastante eficiente (...), de outro lado, no que diz respeito às rodadas de negociação, muitas nações ou blocos de nações aumentaram substantivamente seu poder de barganha no comércio internacional, tornando esses atores capazes de obstruir qualquer negociação, embora cada nação ou grupo de nação continuem incapazes de arbitrar conflitos e resolver impasses. ${ }^{7}$

Mas, em que pesem as críticas, o fato é que a Organização Mundial do Comércio nasce como a grande promessa para a regulação do comércio internacional. As principais falhas apontadas no GATT são solucionadas, sendo criado um sistema de solução de controvérsias que se apresenta como a grande inovação da Rodada Uruguai.

A OMC apresenta uma estrutura organizada, sendo a Conferência Ministerial o seu órgão máximo. A Conferência Ministerial se reúne no máximo em cada dois anos, todos os membros se fazem representar, através dos chefes de Estados ou seus Ministros das Relações Exteriores. É o órgão responsável pelas principais decisões que envolvem a Organização.

7 SATO, Eiiti. De GATT para OMC e a Agenda do Brasil no Comércio Internacional. In: ALTEMANI,Henrique \& LESSA, Antônio Carlos (Orgs.). Relações Internacionais do Brasil: Temas e agendas. Volume 2. São Paulo: Ed. Saraiva, 2006, p.156 
O Conselho Geral, órgão que se apresenta hierarquicamente abaixo da Conferência Ministerial, se reúne com mais freqüência do que o referido Conselho, aproximadamente uma vez por mês. Todos os membros também se fazem representar, em geral por um membro da sua missão diplomática em Genebra.

Para melhor visualização, apresentamos quadro estrutural extraído do site da Organização ${ }^{8}$ :

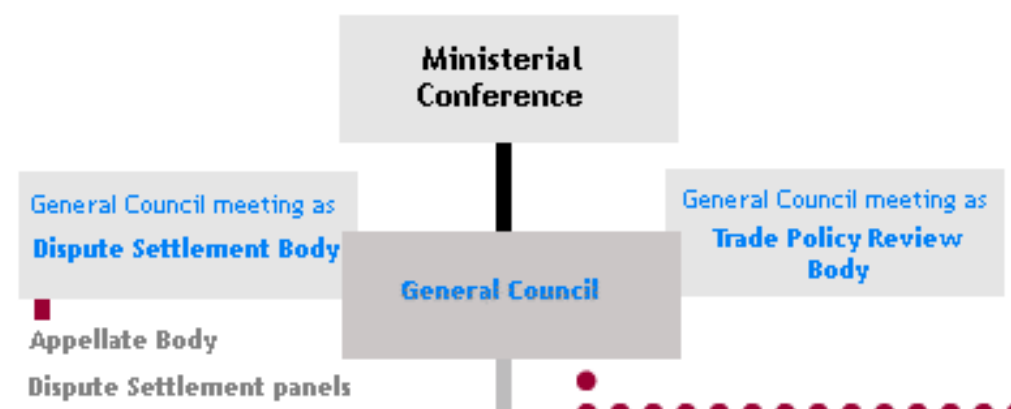

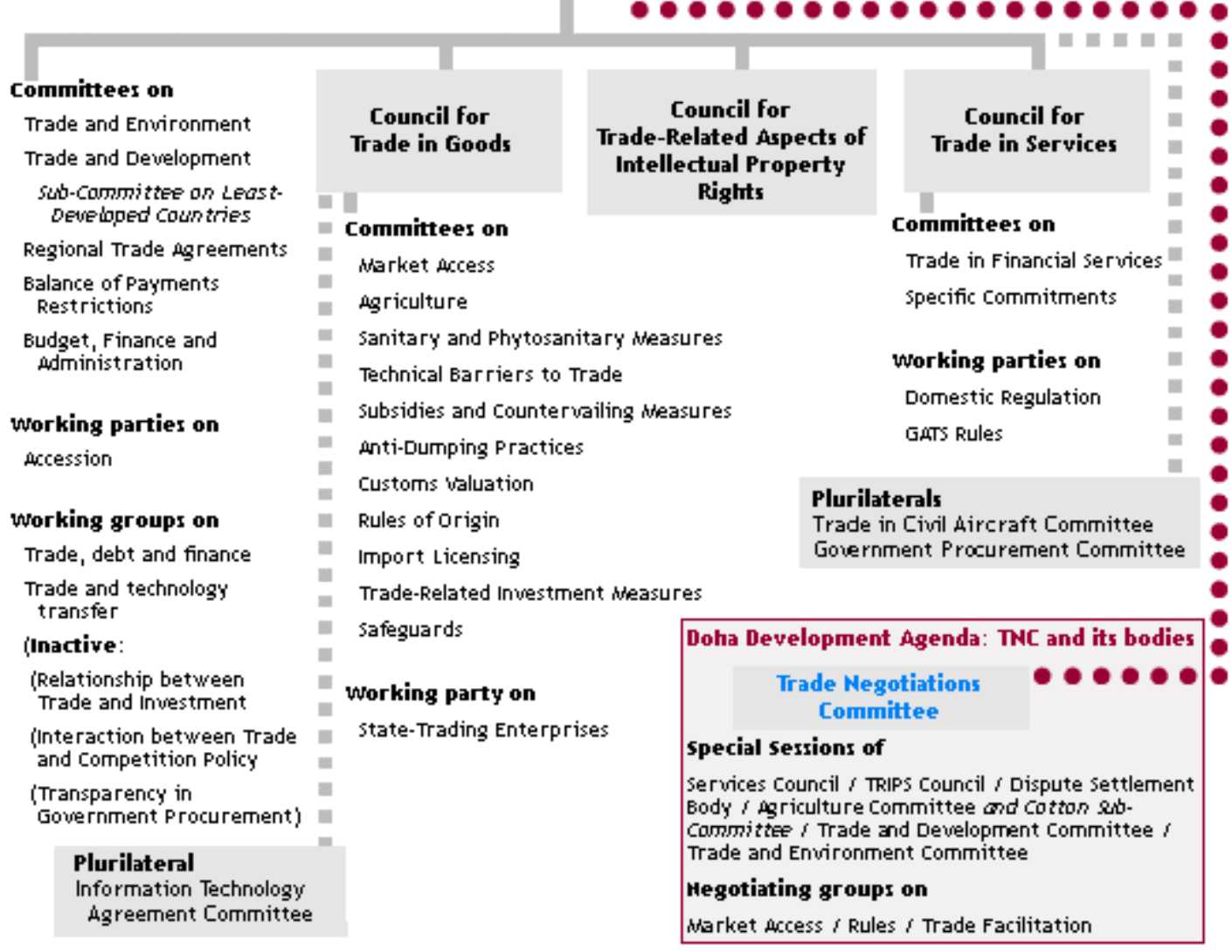

Key

Reporta-se ao Conselho Geral (ou a suas subsidiárias) ${ }^{9}$

${ }^{8}$ Extraído do portal da OMC: http://www.wto.org/english/thewto_e/whatis_e/tif_e/org2_e.htm, acesso em 11.02.2011.

${ }^{9}$ Tradução livre do inglês: "Reporting to General Council (or a subsidiary)". Extraído do portal da OMC: http://www.wto.org/english/thewto_e/whatis_e/tif_e/org2_e.htm, acesso em 11.02.2011. 
Reporta-se ao Órgão de Solução de Controvérsias ${ }^{10}$

Comites plurilaterais informam o Conselho Geral ou o Conselho de Bens referente a

n - " suas atividades. Note-se que esses acordos não são assinados por todos os Membros da OMC ${ }^{11}$

— O Comite de Negociações de Comerciais reporta-se ao Conselho Geral ${ }^{12}$

Assim, o Conselho Geral, órgão imediato inferior a Conferência Ministerial tem como regra que as suas decisões devem ser tomadas por consenso, onde nenhum membro pode votar contra o que está sendo decidido. Os acordos também podem prever decisões por maioria, mas tal fato deve estar expressamente ajustado pelas regras da OMC.

Ao Conselho Geral estão subordinados: o Conselho de Comércio de Bens, o Conselho de Propriedade Intelectual e o Conselho de Comércio de Serviços.

\subsection{O Sistema de Solução de Controvérsias da OMC}

Dessa maneira, após breve demonstrativo da estrutura organizacional da OMC, passamos a analisar o seu sistema de solução de controvérsias.

Como dito, logo na Rodada do Uruguai, no ano de 1994 é ajustado entre os membros da recém criada Organização Mundial do Comércio o Entendimento sobre Solução de Controvérsias - ESC, ou, Dispute Settlement Understanding - DSU, sistema de solução de controvérsias inovador, que surge com a promessa de regular o comércio internacional, evitando, dessa forma, um maior confronto entre os países membros.

A adoção do sistema de solução de controvérsias foi, sem dúvida, o mais significativo resultado da Rodada Uruguai. Sem um mecanismo eficiente para solucionar conflitos, um sistema baseado em regras ficaria enfraquecido, uma vez que as regras não seriam cumpridas. As razões que podem ser apontadas por uma avaliação positiva do mecanismo são de

\footnotetext{
${ }^{10}$ Tradução livre do inglês: "Reporting to Dispute Settlement Body". Extraído do portal da OMC: http://www.wto.org/english/thewto_e/whatis e/tif_e/org2_e.htm, acesso em 11.02.2011.

${ }^{11}$ Tradução livre do inglês: "Plurilateral committees inform the General Council or Goods Council of their activities, although these agreements are not signed by all WTO members” Extraído do portal da OMC: http://www.wto.org/english/thewto_e/whatis_e/tif_e/org2_e.htm, acesso em 11.02.2011.

${ }^{12}$ Tradução livre do inglês: “Trade Negotiations Committee reports to General Council” Extraído do portal da OMC: http://www.wto.org/english/thewto_e/whatis_e/tif_e/org2_e.htm, acesso em 11.02.2011.
} 
que o sistema se tornou mais forte porque foi definido todo um procedimento de análise dos casos, estabelecimento de prazos, chegado a conclusões, e imposição de sanções a infratores. ${ }^{13}$

Com o Entendimento sobre Solução de Controvérsias é criado o Órgão de Solução de Controvérsias - OSC, formado por todos os membros da OMC, o Órgão de Apelação, formado por 07 (sete) integrantes independentes e, ainda, um grupo especial, escolhido para compor os painéis, responsável pela elaboração do parecer técnico sobre a lide.

Os membros da OMC se reúnem regularmente para a tomada de decisões, sendo o processo decisório do OSC baseado no consenso. Como uma das grandes alterações na tomada da decisão, diferenciando-se do GATT, o consenso no OSC significa aduzir que se nenhum membro votar contra a decisão estará tomada. Não há necessidade de que todos votem a favor, favorecendo, dessa forma os países que não podem estar presentes quando da tomada de decisões.

As regras adotadas pelo OSC estão previstas no Entendimento de Solução de Controvérsias. Nas palavras de Carla Junqueira:

As regras sobre o sistema de solução de controvérsias da OMC encontram-se fixadas no Entendimento sobre a Solução de Controvérsias (ESC), ou Dispute Settlement Understanding (DSU), que é parte integrante do Acordo Constitutivo da OMC. O ESC é um sistema integrado para solução de controvérsias que se aplica a todos os acordos abrangidos. $^{14}$

Welber Barral nos ensina que além de abranger todos os acordos da OMC, o ESC é responsável pela criação de uma jurisdição compulsória que obriga todos os seus membros, que devem recorrer e atacar as normas e procedimentos do Entendimento. A parte que se sente prejudicada deve identificar a regra violada e a possibilidade jurídica da reclamação tem que estar formulada a partir de (a) qualquer benefício decorrente do acordo estar sendo anulado ou prejudicado

\footnotetext{
13 THORSTENSEN, Vera. OMC - Organização Mundial do Comércio: as regras do comércio internacional e a rodada do milênio. São Paulo: Aduaneira, 1999. P. 341.

${ }^{14}$ JUNQUEIRA, Carla. O Brasil e o Contencioso na OMC: Tomo II. SãoPaulo: Saraiva, 2009. p. 268
} 
(nullification); ou (b) o atingimento de qualquer objetivo do acordo estar sendo impedido (impairment). ${ }^{15}$

Welber Barral explica, ainda, que:

O ESC consolidou uma visão mais legalista (rule-oriented) das relações comerciais internacionais; ao mesmo tempo, manteve algumas importantes brechas para que as soluções negociadas fossem preferíveis ao litígio entre os Membros da $\mathrm{OMC}^{16}$

Assim, o ESC tem a função de regular os conflitos existentes de competência da OMC. O Art. 2:1 do ESC descreve que as suas atribuições são de: estabelecer painéis, acatar o relatório daqueles, bem como do Órgão de Apelação, supervisionar a aplicação das decisões e de outras obrigações determinadas pelos acordos abrangidos.

A parte que se sentir prejudicada deve primeiramente apresentar reclamação explicitando os fatos para o Órgão de Solução de Controvérsias. Haverá tentativas de conciliação entre as partes, inclusive sendo o país consultado previamente, e, caso tais tentativas resultem infrutíferas e a resposta à consulta seja insatisfatória, o OSC abrirá um painel, onde três especialistas emitirão relatório sobre o assunto.

Do relatório mencionado cabe recurso ao Órgão de Apelação. Após análise da apelação, é elaborado o relatório final que deve ser obedecido pelas partes envolvidas. Ressalta-se que as partes que possuem interesse na solução da contenda podem funcionar no processo como terceiros interessados.

O não cumprimento da decisão enseja a aplicação de sanções, aprovada pelo Órgão de Solução de Controvérsias. Porém, o próprio Entendimento de Solução de Controvérsias afirma que a implementação da recomendação/decisão é preferível a qualquer sanção. Ou seja, a sanção é imposta como meio de fazer o Membro cumprir com as regras da OMC e não como forma de substituir a referida implementação.

\footnotetext{
${ }^{15}$ BARRAL, Weber, organizador. Solução de Controvérsias na Organização Mundial do Comércio. Brasília: Ministério das Relações Exteriores: Fundação Alexandre Gusmão, 2007. P. 23

${ }^{16}$ BARRAL, Welber, organizador. Solução de Controvérsias na Organização Mundial do Comércio. Brasília: Ministério das Relações Exteriores: Fundação Alexandre Gusmão, 2007. P. 19
} 
Faz-se a observação de que apesar do Órgão de Solução de Controvérsias exigir o consenso para a tomada de decisões, conforme acima explicitado, nas decisões fundamentais para o Sistema de Solução de Controvérsias, como o estabelecimento dos painéis, a adoção dos relatórios, a adoção da decisão do Órgão de Apelação e para a autorização de suspensão de concessões é exigido o consenso reverso, onde apenas nos casos de todos os membros votarem contra é que não haverá a adoção da decisão em questão.

A grande crítica que se faz ao Sistema de Solução de Controvérsias ocorre justamente na fase de implementação da decisão. Como coibir os membros a acatarem os relatórios dos painéis ou do Órgão de Apelação? As diferenças havidas entre os países desenvolvidos e os países em desenvolvimento, e também destes em relação aos países com menor desenvolvimento relativo tende a ficar mais evidente na fase onde a decisão do Órgão de Solução de Controvérsias deve ser implantada.

Há que se levar em consideração na discussão sobre o tema que, com a existência de novos atores e organizações internacionais, cada vez mais Estados podem participar dos processos decisórios, e, conseqüentemente, da criação de novas normas, ressaltando, ainda mais, a importância das normas como instrumento capaz de favorecer a interdependência entre os Estados, como é o caso do Entendimento de Solução de Controvérsias. Ou seja, há aceitação prévia dessas normas, que são analisadas quando há a decisão do Estado em adentrar na Organização Internacional.

Porém, mesmo existindo a referida interdependência, e, mesmo os países aceitando a existência de normas reguladoras, as nações desenvolvidas tendem a não cumprir os mandamentos da OMC, uma vez que os países em desenvolvimento e de menor desenvolvimento relativo não possuem poder coercitivo para tanto. $\mathrm{O}$ Entendimento de Solução de Controvérsias oferece alguns instrumentos de coerção, como, por exemplo, a possibilidade de retaliação, desde que autorizada. Porém, o membro que fará a retaliação deve ter força política e econômica para arcar com as suas conseqüências.

As críticas sobre o sistema dividem os especialistas. Em que pese essa questão, de forma geral, há o entendimento de que o Sistema de Solução de Controvérsias da OMC tem se mostrado, de certa forma, eficiente, posto que o número de países em desenvolvimento demandantes tem aumentado. 
Atualmente existem diversas disputas em curso na OMC. Porém pergunta-se: o Sistema de Solução de Controvérsias é eficiente para os países em desenvolvimento? Os países desenvolvidos aceitam as decisões? Há realmente o cumprimento das decisões?

Passa-se, assim, à análise de casos envolvendo o Brasil, para que ao fim, se possa fazer uma análise, ainda que breve, dos questionamentos acima. 


\section{CAPÍTULO II - O BRASIL E A ORGANIZAÇÃO MUNDIAL DO COMÉRCIO}

\subsection{A participação do Brasil na OMC}

O Brasil se apresenta como um dos países em desenvolvimento mais ativos na utilização dos mecanismos do Órgão de Solução de Controvérsias da Organização Mundial do Comércio. Já participou de 25 casos como demandante, 14 casos como demandado e 61 como terceira parte, conforme dados extraídos do site da Organização ${ }^{17}$.

Dentre os casos que participou como demandante temos:

\begin{tabular}{|c|c|c|}
\hline \multirow{9}{*}{ Brasil } & EUA & $\begin{array}{l}\text { DS4 - Padrões para a gasolina } \\
\text { convencional e reformulada }\end{array}$ \\
\hline & Comunidade Europeia & $\begin{array}{l}\text { DS69 - Medidas relativas à } \\
\text { importação de certas aves } \\
\text { domésticas }\end{array}$ \\
\hline & Canadá & $\begin{array}{l}\text { DS70 - Medidas relativas à } \\
\text { exportação de aeronaves civis }\end{array}$ \\
\hline & Canadá & $\begin{array}{l}\text { DS71 - Medidas relativas à } \\
\text { exportação de aeronaves civis }\end{array}$ \\
\hline & Peru & $\begin{array}{l}\text { DS112 - Investigação de direitos } \\
\text { compensatórios sobre } \\
\text { importações de ônibus do Brasil }\end{array}$ \\
\hline & Comunidade Europeia & $\begin{array}{l}\text { DS154 - Medidas relativas ao } \\
\text { tratamento diferencial e favorável } \\
\text { ao café }\end{array}$ \\
\hline & Argentina & $\begin{array}{l}\text { DS190 - Medidas de salvaguarda } \\
\text { transitórias sobre certas } \\
\text { importações de produtos têxteis } \\
\text { de algodão e misturas de algodão } \\
\text { originados no Brasil }\end{array}$ \\
\hline & Turquia & $\begin{array}{l}\text { DS208 - Direito antidumping } \\
\text { sobre conexões de aço e ferro }\end{array}$ \\
\hline & Comunidade Europeia & $\begin{array}{l}\text { DS209 - Medidas relativas ao } \\
\text { café solúvel }\end{array}$ \\
\hline
\end{tabular}

\footnotetext{
${ }^{17}$ Informações extraídas do site da OMC: < http://www.wto.org/>. Acesso em: 10.12.2010
} 


\begin{tabular}{|c|c|}
\hline México & $\begin{array}{l}\text { DS216- Medida antidumping } \\
\text { provisória sobre transformadores } \\
\text { elétricos }\end{array}$ \\
\hline EUA & $\begin{array}{l}\text { DS217 - Lei de compensação por } \\
\text { dumping e subsídio continuado } \\
\text { de } 2000\end{array}$ \\
\hline EUA & $\begin{array}{l}\text { DS218 - Medidas compensatórias } \\
\text { sobre certos produtos } \\
\text { siderúrgicos do Brasil }\end{array}$ \\
\hline Comunidade Europeia & $\begin{array}{l}\text { DS219 - Direitos antidumping } \\
\text { sobre tubos e conexões de ferro } \\
\text { fundido maleável do Brasil }\end{array}$ \\
\hline Canadá & $\begin{array}{l}\text { DS222 - Créditos à exportação e } \\
\text { garantias de empréstimos para } \\
\text { aeronaves regionais }\end{array}$ \\
\hline EUA & DS224 - Leis de patente dos EUA \\
\hline EUA & $\begin{array}{l}\text { DS239 - Direitos antidumping } \\
\text { sobre silício metálico do Brasil }\end{array}$ \\
\hline Argentina & $\begin{array}{l}\text { DS241 - Direitos antidumping } \\
\text { relativos ao frango do Brasil }\end{array}$ \\
\hline EUA & $\begin{array}{l}\text { DS250 - Imposto de equalização } \\
\text { do estado da Flórida sobre os } \\
\text { produtos de laranja e grapefruit }\end{array}$ \\
\hline EUA & $\begin{array}{l}\text { DS259 - Medidas de salvaguarda } \\
\text { definitiva sobre importações de } \\
\text { certos produtos siderúrgicos }\end{array}$ \\
\hline Comunidade Europeia & $\begin{array}{l}\text { DS266 - Subsídios à exportação } \\
\text { do açúcar }\end{array}$ \\
\hline EUA & DS267 - Subsídios ao algodão \\
\hline Comunidade Europeia & $\begin{array}{l}\text { DS269 - Classificação aduaneira } \\
\text { do frango desossado congelado }\end{array}$ \\
\hline EUA & $\begin{array}{l}\text { DS365 - Suporte doméstico e } \\
\text { garantias de crédito de } \\
\text { exportação para produtos } \\
\text { agrícolas }\end{array}$ \\
\hline EUA & $\begin{array}{l}\text { DS382 - Revisões } \\
\text { administrativas antidumping e } \\
\text { outros medidas relacionadas à } \\
\text { importação de certos sucos de } \\
\text { laranja do Brasil }\end{array}$ \\
\hline União Europeia e um Estado & DS409 - Confisco de remédios \\
\hline
\end{tabular}


São os seguintes os painéis em que participou como demandado:

\begin{tabular}{|c|c|c|}
\hline \multirow{14}{*}{ Brasil } & Filipinas & $\begin{array}{l}\text { DS22 - Medidas referentes ao } \\
\text { coco ralado }\end{array}$ \\
\hline & Sri Lanka & $\begin{array}{l}\text { DS30 - Medidas compensatórias } \\
\text { referentes ao coco ralado em pó } \\
\text { proveniente do Sri Lanka }\end{array}$ \\
\hline & Canadá & $\begin{array}{l}\text { DS46 - Programa de } \\
\text { financiamento à exportação de } \\
\text { aeronaves }\end{array}$ \\
\hline & Japão & $\begin{array}{l}\text { DS51 - Certas medidas de } \\
\text { investimento no setor } \\
\text { automotivo }\end{array}$ \\
\hline & EUA & $\begin{array}{l}\text { DS52 - Certas medidas relativas } \\
\text { ao comércio e investimento no } \\
\text { setor automotivo }\end{array}$ \\
\hline & EUA & $\begin{array}{l}\text { DS65 - Certas medidas relativas } \\
\text { ao comércio e investimento no } \\
\text { setor automotivo }\end{array}$ \\
\hline & Comunidade Europeia & $\begin{array}{l}\text { DS81 - Certas medidas relativas } \\
\text { ao comércio e investimento no } \\
\text { setor automotivo }\end{array}$ \\
\hline & Comunidade Europeia & $\begin{array}{l}\text { DS116 - Medidas relativas a } \\
\text { prazos de pagamentos para } \\
\text { importações }\end{array}$ \\
\hline & Comunidade Europeia & $\begin{array}{l}\text { DS183 - Medidas sobre } \\
\text { licenciamento a importações e } \\
\text { preços mínimos de importação }\end{array}$ \\
\hline & EUA & $\begin{array}{l}\text { DS197 - Medidas sobre preços } \\
\text { mínimos de importação }\end{array}$ \\
\hline & EUA & $\begin{array}{l}\text { DS199 - Medidas referentes à } \\
\text { proteção patentária }\end{array}$ \\
\hline & India & $\begin{array}{l}\text { DS229 - Direitos antidumping } \\
\text { sobre sacos de juta provenientes } \\
\text { da Índia }\end{array}$ \\
\hline & Comunidade Europeia & $\begin{array}{l}\text { DS332 - Medidas relativas à } \\
\text { importação de pneus reformados }\end{array}$ \\
\hline & Argentina & DS355 - Medidas antidumping \\
\hline
\end{tabular}




\begin{tabular}{|l|l|}
\hline & $\begin{array}{l}\text { sobre a importação de certas } \\
\text { resinas da Argentina }\end{array}$ \\
\hline
\end{tabular}

$\mathrm{Na}$ vasta relação de contenciosos, pode-se destacar aquele havido entre Brasil e Estados Unidos, conhecido como caso do algodão; Brasil e União Europeia, caso do açúcar e Brasil.

A seguir se fará, em apertada síntese, a demonstração dos casos acima citados. Repita-se que os casos se apresentarão de forma resumida, uma vez que a finalidade é se analisar o cumprimento das decisões emanadas pela Organização Mundial do Comércio e não os casos propriamente ditos.

\subsection{O Caso do Algodão}

A disputa envolvendo os subsídios agrícolas (WT/DS 267) concedidos aos produtores locais pelos Estados Unidos foi iniciada pelo Brasil, em 27 de setembro de 2002, sendo considerado um dos casos mais relevantes já julgados pelo Órgão de Solução de Controvérsias. Figuraram como terceiras partes: Argentina, Austrália, Benin, Canadá, Chade, China, Comunidades Europeias, Índia, Japão, Nova Zelândia, Paquistão, Paraguai, Taiwan e Venezuela

O caso se iniciou com uma consulta apresentada pelo Brasil aos Estados Unidos, bem como ao Órgão de Solução de Controvérsias questionando a incompatibilidade dos programas americanos de subsídios agrícolas ao algodão e o os acordos firmados no âmbito da $\mathrm{OMC}^{18}$.

Cabe explicar que os governos se utilizam dos subsídios como forma de incrementar a sua economia interna, e, conseqüentemente externa, realizando investimentos ou facilitação de crédito em determinado setor, com vistas a apoiar a sua produção. Com a ajuda de subsídios o setor passa a se desenvolver e adquire vantagem competitiva, uma vez que detém recursos assegurados pelo governo que lhe permitem, a depender do caso, jogar com os preços e desestabilizar o setor.

\footnotetext{
${ }^{18}$ ARAÚJO, Leandro R. e outros. Agricultura e Subsídios: o “Caso do Algodão”. In LIMA, Maria Lúcia L.M. \& ROSERNBERG, Barbara. (Orgs.) Solução de Controvérsias: O Brasil e o Contencioso na OMC: Tomo I. São Paulo: Saraiva, 2009. p. 255
} 
Os Membros da OMC são signatários do Acordo de Subsídios e Medidas Compensatórias, mas, em que pese a regulação dos subsídios, eles são utilizados, por diversas vezes, de forma ilegal pelos países membros. Os subsídios oferecem vantagens que podem desestabilizar o comércio internacional, uma vez que os produtos têm condições de serem produzidos a baixo custo, diminuindo o seu valor de venda. O produto passa a ser adquirido internamente a preço baixo, e também exportado dessa maneira.

As suspeitas de desatendimento aos acordos firmados perante a OMC se iniciaram quando houve o aumento da produção e exportação norte-americana de algodão, justamente no momento em que os preços internacionais estavam em declínio. Ora, tal fato só poderia ser devido ao fato dos produtores estarem recebendo auxílio do governo, motivo que ensejaria a demanda perante o Órgão de Solução de Controvérsias.

A consulta se referia às seguintes medidas norte-americanas:

Marketing Loan Programme, programa que se iniciou no ano de 1986, tendo como principal objetivo compensar possíveis perdas decorrentes das variações de preços do açúcar no decorrer do ano. O programa permitia, assim, que os produtores estocassem as suas commodities para vendê-las no momento oportuno, sem que houvessem perdas.

Step 2 Programme, programa iniciado no início dos anos noventa, visando ofertar financiamentos aos usuários domésticos e/ ou produtores e/ou exportadores quando algumas condições, como alta de preços, fossem verificadas.

Production Flexibility Contract (PFC), programa utilizado até 30 de setembro de 2002, concedia pagamentos auxílio aos produtores, baseado na área plantada e na produção das seguintes commodities: algodão, trigo, milho, sorgo, aveia, arroz e cevada.

Market Loss Assistance (MLA), programa criado para fornecer assistência emergencial para produtores com condições de receber o PFC, acima citado, com o objetivo de recuperar eventual prejuízo acarretado pela baixa de preços das commodities, inclusive o algodão.

Director Payments (DP): programa parecido com o PFC, cujo objetivo era auxiliar os produtores das 07 (sete) commodities do PFC, mais a soja e o 
amendoim. O auxílio era prestado nos mesmos moldes do PFC, ou seja, levando em consideração a área plantada, bem como a produção histórica para novas commodities.

Counter-Cyclical Payments (CCP): programa similar ao DP, porém, a sua concessão guarda relação direta com os preços correntes das commodities.

Crop Insurance Payments (CIP), programa similar a de um seguro, assegurando os produtores tanto em casos de desastres naturais quanto flutuações de preços.

Cottonseed Payments, programa que ofereceu auxílio aos produtores de sementes de algodão, bem como às pessoas responsáveis pela sua separação. O pagamento foi calculado dividindo-se os produtores elegíveis pelo fundo disponível.

Export Credit Guarantee, nome dado à junção dos três programas cujo objetivo é apoiar a exportação de commodities, quais sejam: General Sales Manager 102, General Sales Manager 103 e o Supplier Credit Guarantee Programme. ${ }^{19}$

Nas palavras de Leandro R. de Araújo:

"Na visão brasileira, esses subsídios agrícolas estariam sendo concedidos em desacordo com os compromissos firmados pelos EUA durante a Rodada Uruguai, bem como em violação às disciplinas do AA, do ASMC e do GATT 1994, em vigor desde $1^{\circ}$ de janeiro de 1995.

Foram justamente os impactos causados pelas políticas agrícolas norteamericanas para o algodão, bem como as regras em vigor para os subsídios agrícolas, que motivaram o Brasil a apresentar pedido de consultas aos EUA, perante o OSC da OMC, a respeito dos mencionados programas norte-americanos e seus reflexos para o mercado internacional de algodão". ${ }^{20}$

\footnotetext{
${ }^{19}$ LIMA, Ieda Miyuki Dias de. Síntese dos Contenciosos do Brasil no OSC da OMC. In LIMA, Maria Lúcia L.M. \& ROSERNBERG, Barbara. (Orgs.) Solução de Controvérsias: O Brasil e o Contencioso na OMC: Tomo II. São Paulo: Saraiva, 2009. p. 324

${ }^{20}$ ARAÚJO, Leandro R. e outros. Agricultura e Subsídios: o "Caso do Algodão”. In LIMA, Maria Lúcia L.M. \& ROSERNBERG, Barbara. (Orgs.) Solução de Controvérsias: O Brasil e o Contencioso na OMC: Tomo I. São Paulo: Saraiva, 2009. p. 258
} 
Após o recebimento da resposta à consulta, concluiu-se não serem satisfatórias as explicações fornecidas pelos Estados Unidos. Na data de 18 de março de 2003 foi estabelecido o painel para examinar o caso.

O Brasil alegava que os Estados Unidos violavam o Acordo de Subsídios e Medidas Compensatórias (ASMC) da OMC, em seus artigos 5 (c), 6.3 (b), (c) e (d), 3.1 (a) e (b) e 3.2, bem como o Acordo sobre Agricultura em seus artigos 3.3, 7.1, 8, 8.1 e 10.1 e o GATT/1994. Assim, o Brasil contestava tanto os chamado subsídios “proibidos” quanto os “acionáveis”.

O painel, ao analisar a demanda, concluiu que a política de subsídios dos Estados Unidos influenciou o preço do algodão no mercado internacional. Inconformado, os Estados Unidos apresentaram recurso ao Órgão de Apelação. Em 2005 o Órgão de Apelação confirmou o ganho de causa em relação ao Brasil.

O precedente criado pelo Brasil é de extrema relevância para o mercado internacional, no tocante aos subsídios agrícolas fornecidos. O Órgão de Solução de Controvérsias proferiu entendimentos que fortalecerão o comércio mundial, ofertando aos países garantias de que não haverá aceitação na concessão de subsídios agrícolas, um grande entrave quando da criação da OMC.

No julgamento do presente caso julgou-se a violação da Cláusula de Paz, ou seja, mesmo com a presença da referida cláusula, o Órgão de Solução de Controvérsias entendeu que os subsídios podem (e devem) ser questionados, uma vez que não há que se tolerar que países desafiem as normas da OMC.

O Órgão também proferiu importante entendimento ao aduzir que mesmos os programas que já tinham sido extintos podem ser alvo de constatação, se houverem prejudicado o Membro demandante. Assim, abre-se um precedente para que os subsídios que, mesmo extintos, causem prejuízos a algum membro de OMC, sejam contestados.

No mesmo sentido decidiu o Órgão de Solução de Controvérsias ao estatuir que programas de garantia de crédito são, de fato, subsídios que podem ir de encontro às normas da OMC.

Desta forma, essas questões, somadas à prova de grave prejuízo ao Brasil, foram consideradas quando da análise do caso. A vitória do Brasil no caso dos subsídios concedidos aos exportadores de algodão americano fortalece a 
independência do órgão em relação às nações desenvolvidas, ao passo que busca equilibrar as relações de comercio internacionais.

\subsection{O Contencioso do Açúcar}

A disputa envolvendo os subsídios ao açúcar concedidos pela União Europeia, chamada na OMC de Comunidade Europeia, teve inicio em setembro de 2002 após Brasil, Austrália e Tailândia apresentarem consulta indagando a legalidade dos mencionados subsídios.

O Brasil questionava

“o fato de que a exportação subsidiada anual de açúcar pela CE ultrapassava os compromissos de redução assumidos pelo bloco perante a OMC e acarretava danos ao Brasil por meio da redução dos preços mundiais e do deslocamento de suas exportações em terceiros mercados. Mais especificamente, a CE não incluía, no cômputo dos seus compromissos de redução de subsídios juntos à OMC, a exportação de “açúcar C” e a reexportação do açúcar originário de países ACP”. ${ }^{21}$

Resumindo os fatos tem-se que: em 1998 a Comunidade Europeia criou a Organização Comum do Mercado de Açúcar (OCM), concedendo diversos incentivos à produção e exportação do açúcar.

Segundo Ieda Miyuki de Lima ${ }^{22}$, a OCM estabelecia duas cotas produtivas para o regime do açúcar produzido na Europa, as cotas de açúcar “A” e “B”, respectivamente de 11,894,223.30 e 5,587,919.20 toneladas. Essas cotas se beneficiariam dos subsídios à exportação e do suporte de preço doméstico. A parte excedente de açúcar, ou seja, o montante que ultrapasse o limite de toneladas previsto, faria parte de uma cota “C”, que não poderia usufruir do suporte de preço, tampouco do subsídio à exportação.

\footnotetext{
${ }^{21}$ AQUINO, Christiane e outros. O Contencioso entre Brasil e Comunidades Europeias sobre os Subsídios ao Açúcar (DS 266). In LIMA, Maria Lúcia L.M. \& ROSERNBERG, Barbara. (Orgs.) Solução de Controvérsias: O Brasil e o Contencioso na OMC: Tomo I. São Paulo: Saraiva, 2009. p. 327

${ }^{22}$ LIMA, Ieda Miyuki Dias de. Síntese dos Contenciosos do Brasil no OSC da OMC. In LIMA, Maria Lúcia L.M. \& ROSERNBERG, Barbara. (Orgs.) Solução de Controvérsias: O Brasil e o Contencioso na OMC: Tomo II. São Paulo: Saraiva, 2009. p. 320
} 
Ieda Miyuki continua explicando que a OCM também previa a garantia de um preço mínimo devido pela importação do açúcar proveniente dos países “ACP”. Explica-se que a denominação “países ACP” se refere às ex-colônias europeias na África, Caribe e no Pacífico.

Assim, o que Brasil, Austrália e Tailândia questionavam era: a concessão de benefícios superiores ao permitidos pela $\mathrm{OMC}$, bem como a extrapolação da reexportação subsidiada do açúcar dos países “ACP” e o efeito spill over dos subsídios concedidos paras as cotas de produção internas, uma vez que o açúcar da cota “C” se beneficiava dos subsídios destinados às cotas “ $A$ ” e " $B$ ” e podia ser comercializado no mercado internacional por um preço bem reduzido.

Conforme já explicado acima, subsídios nada mais são do que um aporte financeiro, ou concessão de vantagens, realizados para fomentar determinado segmento de negócio. Assim, os efeitos dos subsídios ofertados pela União Europeia representavam grande impacto à economia mundial, especialmente aos países produtores de açúcar, ainda mais quando se analisa a dimensão e proporção do comércio realizado pelo bloco econômico.

Assim, tendo a resposta às consultas sido insatisfatória, na data de 29 de agosto de 2003 foi estabelecido o painel para análise das questões. Em 15 de outubro de 2004 o painel decidiu a favor dos demandantes, concordando com o fato de os subsídios extrapolarem o permitido pelas regras da OMC.

A Comunidade Europeia não conseguiu demonstrar que as exportações do açúcar “C” não recebiam subsídios, até porque ocorria, como visto, transferência financeira, ainda que indireta, das vendas do açúcar “A” e "B”.

Nas palavras de Christiane Aquino:

“O painel, de acordo com o Artigo 19.1 do Entendimento sobre Solução de Controvérsias (ESC), recomendou que exportações comunitárias de açúcar passassem a respeitar as obrigações dos Artigos 3.3 e 8 do AA e que a CE considerasse promover a diminuição da produção de açúcar, obedecendo à demanda doméstica e respeitando os compromissos internacionais relacionados à importação de açúcar, sobretudo com PEDs 
- em uma expressa referência aos acordos preferenciais com os países ACP”. ${ }^{23}$

O Órgão de Apelação confirmou a decisão do painel, proferindo entendimento de que a Comunidade Europeia estava ultrapassando o montante que poderia subsidiar. Conclui-se que havia transferência financeira de recursos das vendas do açúcar “A” e do açúcar "B” para o açúcar “C”, bem como desconsiderou a nota de rodapé utilizada como defesa pela Comunidade Europeia, uma vez que a CE alegava que o Brasil concordou com a forma de subsídios do açúcar ACP em acordo firmado no âmbito da OMC.

Explica-se que de fato o Brasil assinou renúncia de direitos autorizando a que as ex-colônias europeias recebessem regime preferencial, mas os argumentos do Brasil, acatados pelo Órgão de Apelação, são no sentido de que a Comunidade Europeia não poderia fazê-lo prejudicando os demais membros.

A ajuda às ex-colônias era possível, desde que feita com dinheiro da Comunidade Europeia, e não em decorrência de prejuízos acarretados em razão de deslocamento de exportações. No relatório ficou comprovado que a quantidade de açúcar advindo dos países ACP estava em desacordo com o compromisso firmado no âmbito da OMC, e, portanto, não podia prevalecer.

Desta maneira, adotados os relatórios finais da apelação e do painel, sagrou-se o Brasil vencedor da contenda. Em maio de 2005 iniciou-se a contagem do prazo para implementação da decisão.

${ }^{23}$ AQUINO, Christiane e outros. O Contencioso entre Brasil e Comunidades Europeias sobre os Subsídios ao Açúcar (DS 266). In LIMA, Maria Lúcia L.M. \& ROSERNBERG, Barbara. (Orgs.) Solução de Controvérsias: O Brasil e o Contencioso na OMC: Tomo I. São Paulo: Saraiva, 2009. p. 355 


\section{CAPÍTULO III - A IMPLEMENTAÇÃO DAS DECISÕES DO ORGÃO DE SOLUÇÃO DE CONTRÓVERSIAS}

\subsection{As críticas que envolvem a implementação das decisões emanadas do Órgão de Solução de Controvérsias.}

A parte mais controversa que envolve as decisões tomadas pelo Órgão de Solução de Controvérsias é a implementação das recomendações e decisões. Como já ressaltado, o Sistema de Solução de Controvérsias da OMC é de suma importância para o controle e regulação do comércio internacional. Sem os mecanismos disponibilizados, não haveria como se controlar a legalidade dos atos dos países membros, comprometendo a própria existência da Organização, como aconteceu com o GATT.

Todos os mecanismos disponibilizados pelo sistema de solução de controvérsias têm como objetivo ofertar segurança aos países membros, e fazer com que as regras e acordos firmados não fiquem apenas no papel. A efetividade e eficácia do Sistema de Solução de Controvérsias estão intimamente ligadas com a implementação das decisões.

Desta feita, após o resultado final dos painéis, inicia-se a fase mais crítica de todo o sistemas. Como fazer com que as decisões sejam implementadas? Primeiramente, deve-se ressaltar que a OMC não visa punir os seus participantes, mas sim assegurar que as regras do comércio internacionais sejam cumpridas, na sua totalidade.

Welber Barral alerta que:

\footnotetext{
“a decisão do OSC não tem caráter reparatório, nem de penalização do Membro que eventualmente tenha transgredido as normas da OMC por meio de uma medida nacional. O objetivo fundamental da fase de implementação, e da eventual suspensão de vantagens, é forçar o Membro
} 
a cumprir a decisão, tornando sua legislação interna compatível com as obrigações que assumiu no âmbito da OMC”. ${ }^{24}$

A implementação das decisões é motivo de várias críticas, que tendem a colocar em dúvida, inclusive, a existência do ordenamento jurídico internacional. O jogo de poder existente entre os países, ou melhor, as diferenças havidas entre os países desenvolvidos e os países em desenvolvimento, e também destes em relação aos países com menor desenvolvimento relativo tendem a ficar mais evidentes e exatamente na fase onde a decisão do Órgão de Solução de Controvérsias deve ser colocada em prática.

Os países em desenvolvimento, mesmo após alcançar a decisão favorável encontram diversas dificuldades em relação ao cumprimento da decisão, especialmente por não possuírem forças quando necessário utilizarem-se da retaliação.

Renato Vargas Amaral explica que:

“A fase de implementação da decisão é hoje o momento mais crítico das disputas enfrentadas no âmbito da OMC. É a fase em que a assimetria de poder de barganha dos Membros fica evidente e quando o legalismo do sistema depara-se com as suas maiores dificuldades. Isso se dá em razão da falta de poder de sanção do mecanismo quando um Membro simplesmente resolve não cumprir uma decisão ou recomendação adotada pelo Órgão de Solução de Controvérsias - OSC, deixando a medida declarada inconsistente continuar prejudicando outros Membros do sistema multilateral de comércio.”25

Assim, quando se precisa medir forças, os países em desenvolvimento ou com menor desenvolvimento relativo saem prejudicados, posto que não representam ameaças aos países desenvolvidos. Às vezes, a adoção de medidas aprovadas pela OMC é mais prejudicial aos países menos desenvolvidos, que devem

\footnotetext{
${ }^{24}$ BARRAL, Welber, organizador. Solução de Controvérsias na Organização Mundial do Comércio. Brasília: Ministério das Relações Exteriores: Fundação Alexandre Gusmão, 2007. P. 59

${ }^{25}$ AMARAL, Renata Vargas. O Distinto Nível de Desenvolvimento dos Países e sua Influência na Falta de Eficácia dos Mecanismos de Execução de Decisões da OMC. Revista dos Tribunais. Volume 872. Disponível na internet: www.revistasrtonline.com.br, acesso em 10.02.2011.
} 
aplicá-las, do que aos países que em tese deveriam ser compelidos a cumprir a recomendação e/ou decisão.

Para que a análise das questões apontadas - dificuldades de implementação das decisões pelos países em desenvolvimento - mister se faz a análise de como se dá a fase de implementação das decisões.

\subsection{A Fase de implementação das decisões e recomendações do Órgão de Solução de Controvérsias}

A fase de implementação das recomendações e decisões do Órgão de Solução de Controvérsias está regulada no artigo 21 do Entendimento de Solução de Controvérsias.

O ESC, em seu artigo 21 acima mencionado, determina que, para o cumprimento das decisões, a parte que se sagrou vencedora deve aguardar a implementação voluntária do julgado, podendo ser estipulado um prazo razoável para o seu cumprimento, quando a implementação não puder se dar imediatamente.

Alternativamente, caso a decisão não seja implementada, o ESC possibilita que o Membro que se recusa a cumprir a determinação compense o Membro vencedor, ou que este suspenda concessões havidas com o descumpridor, após autorização do Órgão de Solução de Controvérsias.

O artigo 21:1, estabelece que "O pronto cumprimento das recomendações e decisões do OSC é fundamental para assegurar a efetiva solução das controvérsias, em benefício de todos os Membros. "26

Vê-se que o ESC determina que a decisão seja cumprida imediatamente, como forma de assegurar a efetividade do próprio Sistema de Solução de Controvérsias. Deve-se ter em mente que tal determinação esbarra, em inúmeras situações, nos próprios mecanismos interno dos países, que devem respeitar o processo legislativo interno para fazerem cumprir as recomendações da Organização Mundial do Comércio.

O ESC determina que o membro interessado, em reunião que deve acontecer no prazo de 30 dias após o encerramento da demanda, deve informar suas

\footnotetext{
${ }^{26}$ Entendimento de Solução de Controvérsias da Organização Mundial do Comércio.
} 
intenções com relação à implementação das decisões. Caso a implementação não possa se dar imediatamente, o membro deve ajustar prazo razoável para que o fato ocorra.

O prazo proposto deve ser aprovado pelo Órgão de Solução de Controvérsias, e, em não havendo a aprovação, as partes podem ajustar de comum acordo o que seria o prazo razoável. Em não havendo acordo, o prazo será determinado em arbitragem, e a recomendação é que não seja superior a 15 meses da data da adoção do relatório do grupo especial ou do Órgão de Apelação, porém, a situação será analisada caso a caso.

Vê-se que a própria norma não é objetiva a tratar do assunto, uma vez que a expressão “prazo razoável” é vaga e dá margem para que uma nova discussão surja entre os demandantes.

Mesmo estipulado, se não cumprido o prazo razoável, o Membro prejudicado deve pensar em retaliação, ao invés de aguardar a boa vontade do Membro infrator em cumprir as determinações do Órgão de Solução de Controvérsias.

Renata Vargas Amaral explica:

\begin{abstract}
"Uma vez vencido o prazo razoável, e em caso de a medida não ter sido colocada em conformidade com as normas do sistema, tecnicamente começa a se gerar uma quantificação do dano causado, que pode dar lugar a uma retaliação. Todavia, para se chegar a este extremo, faz-se necessária a determinação no sentido de verificar que as ações tomadas pelo Membro que resultou vencido na controvérsia não alcançaram um nível satisfatório para remover a inconsistência constatada. Essa determinação está prevista no art. 21:5, do ESC e, segundo Pérez Gabilondo, os Membro da OMC se comprometeram que esta decisão seja fruto da aplicação do mecanismo de solução de controvérsias negociado na Rodada Uruguai, mas não produto da decisão unilateral de um dos Membros."27 $^{27}$
\end{abstract}

\footnotetext{
${ }^{27}$ AMARAL, Renata Vargas. O Distinto Nível de Desenvolvimento dos Países e sua Influência na Falta de Eficácia dos Mecanismos de Execução de Decisões da OMC. Revista dos Tribunais. Volume 872. Disponível na internet: www.revistasrtonline.com.br, acesso em 10.02.2011.
} 


\title{
3.3 Medidas de Compensação e Retaliação - Necessidade de Aprovação pelo Órgão de Solução de Controvérsias
}

Caso não implementado o resultado do relatório aprovado pelo painel, ou Órgão de Apelação, a parte prejudicada pode solicitar ao Órgão de Solução de Controvérsias que sejam aplicadas medidas de compensação, suspensão de concessões ou outras obrigações. O ESC, em seu artigo 22, deixa claro que tais medidas são temporárias e não devem ser preferíveis à total implementação de uma decisão.

As medidas visam à indução do cumprimento da decisão, e devem ser aprovadas pelo Órgão de Solução de Controvérsias. O ESC aduz que as partes devem tentar suspender as concessões no setor objeto da demanda, e, em não havendo acordo nesse sentido, se estudará a suspensão em outro setor.

A adoção das referidas medidas não é algo simples de acontecer, uma vez que os países desenvolvidos possuem vantagens econômicas sobre os demais. $\mathrm{Na}$ maioria das vezes, a suspensão de concessões é mais prejudicial ao país que as aplica do que ao país que deveria implementar uma recomendação da OMC.

Renata Vargas do Amaral bem explicita que:

\begin{abstract}
“O sistema de solução de controvérsias em vigor não soluciona os problemas de assimetria entre os Membros da OMC, e este problema mostra-se evidente na fase de implementação de decisões ou recomendações do OSC. Segundo Hudec, os países desenvolvidos - PD acabam por privilegiar-se com a falta de um mecanismo eficaz que force a implementação de decisões e possibilite a reparação de danos sofridos. O mesmo autor acrescenta que os PD alegam que as disciplinas para alterar substancialmente o mecanismo de implementação de decisões ou recomendações do OSC são ineficazes, opondo-se às iniciativas voltadas à alteração de um sistema que os permitam ferir Membros mais fracos sem serem feridos”, ${ }^{28}$
\end{abstract}

\footnotetext{
${ }^{28}$ AMARAL, Renata Vargas. O Distinto Nível de Desenvolvimento dos Países e sua Influência na Falta de Eficácia dos Mecanismos de Execução de Decisões da OMC. Revista dos Tribunais. Volume 872. Disponível na internet: www.revistasrtonline.com.br, acesso em 10.02.2011. p. 8
} 
Preferencialmente o país deve adotar medidas que envolvam retaliação no mesmo setor (produto) demandado. Porém, o Órgão de Solução de Controvérsias permite que outros setores sejam alvo de retaliação, no que se denomina Retaliação Cruzada. Assim, para obter autorização para praticar a Retaliação Cruzada, o membro interessado deve demonstrar que a retaliação entre setores não é efetiva.

O instituto da Retaliação Cruzada se originou da preocupação dos Estados Unidos em fazer os países em desenvolvimento cumprirem as decisões/recomendações do Órgão de Solução de Controvérsias. O medo dos Estados Unidos erae que, como sua preocupação e demanda recorrente na OMC envolve Propriedade Intelectual, e como os países em desenvolvimento não possuem demandas ou conflitos nessa área, capazes de se obrigarem a cumprir a decisão caso suas marcas e patentes sejam ameaçadas, os países em desenvolvimento não cumprissem as determinações da OMC, posto não existir outros meios de induzi-los a fazê-lo.

Assim, a retaliação cruzada surge para compelir os países em desenvolvimento a cumprirem as decisões, quando envolverem marcas e patentes, podendo ser retaliados, por exemplo, no que se refere à agricultura.

Edgard Marcelo Rocha Torres alerta que:

Todavia, esta previsão funcionou no sentido contrário ao que pretendia os EUA, favorecendo justamente os países em desenvolvimento. De 1995 até 2008, por duas vezes a OMC autorizou a aplicação da retaliação cruzada contra a Comunidade Europeia e os EUA nos casos das Bananas do Equador e do US-Gambling de Antigua e Barbuda, respectivamente, autorizando estes países a suspender os direitos decorrentes do Tratado de Propriedade Intelectual do qual se beneficiavam. Contudo, devido ao pequeno porte destas economias e da total falta de interesse político e econômico em enfrentar os maiores e os mais poderosos países do mundo, as retaliações não foram efetivadas não se chegando a testar as ultimas conseqüências do Sistema de Solução de Controvérsias. $^{29}$

\footnotetext{
${ }^{29}$ TORRES, Edgard Marcelo Rocha. O caso dos subsídios do algodão entre Brasil e EUA. O uso
} efetivo da retaliação cruzada como prova final da eficácia do sistema de solução de controvérsias da 
A retaliação cruzada se torna, dessa maneira, a grande arma dos países em desenvolvimento contra os países desenvolvidos, no intuito de compeli-los a cumprir as decisões emanadas do Órgão de Solução de Controvérsias. O instrumento oferece vantagens tendo em vista que os países em desenvolvimento, quando autorizados a usar a referida retaliação, possuem a chance de suspender os direitos de propriedade intelectual e desenvolver produtos a custos baixos, sem terem que observar a regra de marcas e patentes. Outra vantagem é que os setores interessados na proteção da propriedade intelectual nos países desenvolvidos exercerão grande pressão pela correta implementação da decisão da OMC. ${ }^{30}$

Porém, a retaliação cruzada também oferece desvantagens, uma vez que o país demandante, se não possuir capacidade econômica para realizá-la, por vezes será mais prejudicado do que o membro demandado. Também pode haver conseqüências comerciais internas graves, como prejuízos a importadores e aumento da pirataria, por exemplo. Essa medida, por ser excepcional só foi autorizada em 08 (oito) casos, dos mais de $400^{31}$ já analisados, e apenas países desenvolvidos efetivamente realizaram a retaliação. Os países em desenvolvimento não conseguem exercer esse direito justamente em razão da falta de capacidade econômica para a sua implantação.

Contudo, atualmente a retaliação cruzada é o instrumento mais potente que os países possuem para coagir os países desenvolvidos a implantarem, de maneira eficaz, a decisão proveniente da Organização Mundial do Comércio.

\subsection{Implementação da recomendação - Caso do açúcar}

Após a adoção dos relatórios, tanto do painel, como do Órgão de Apelação, iniciou-se, em maio de 2005, o prazo razoável para que a Comunidade Europeia realizasse a implementação da decisão.

As partes demandantes não conseguiram celebrar um acordo com a Comunidade Europeia. Sendo assim, iniciou-se o procedimento de arbitragem. A

OMC: redenção ou ruína?. Jus Navigandi, Teresina, ano 15, n. 2521, 27 maio 2010. Disponível em: <http://jus.uol.com.br/revista/texto/14927>. Acesso em: 1 abr. 2011.

30 Idem

31 Informação extraída do site do Ministério do Desenvolvimento, Indústria e Comércio: < www.mdic.gov.br/arquivos/dwnl_1268066402.doc>, acesso em 02.04.2011. 
Comunidade Europeia solicitou prazo razoável de quase dois anos para o cumprimento da decisão, o Brasil e os demais países demandantes, após analisarem a legislação da União Europeia verificaram que, se houvesse vontade, a recomendação poderia ser implementada em poucos meses, pelo que solicitaram que a implementação fosse realizada no prazo máximo de 06 meses.

O Órgão de Apelação determinou, apesar das ponderações de ambas as partes, que a legislação deveria ser adequada para comportar o decidido nos relatórios, no prazo razoável de doze meses e três dias, contado da data de adoção dos relatórios, ou seja, 19 de maio de 2005.

Dentre do prazo previsto a Comunidade Europeia apresentou um projeto para a reforma das regras do regime açucareiro, visando cumprir as regras da OMC, determinando, dentre outros, a liberalização da venda do açúcar "C" ao mercado interno, unificação das cotas “A” e “B”, fixação de preço de referência, ao invés de preço de interferência, etc. Assim, haveria diminuição de excedentes de exportação da produção subsidiada, sem as sobras do açúcar “C”, antes proibido de ser comercializado no plano interno, permitindo uma maior competitividade no plano internacional.

O novo regime, porém apenas dava aos países demandantes uma previsão do que aconteceria, uma vez que os resultados só poderiam ser vistos com o passar dos anos. Mas, mesmo assim, as partes envolvidas firmaram um acordo, no mês de junho de 2006, onde os demandantes se comprometiam a passar à fase de retaliação após análise das medidas tomadas, no denominado painel de revisão.

As partes envolvidas também estabeleceram reuniões periódicas para acompanhar a implementação, importando ressaltar que, logo após as medidas tomadas já foi possível notar a diminuição do valor das exportações do açúcar europeu. Atualmente, os efeitos da mudança da legislação do açúcar pela União Europeia são realidade, com mudanças significativas no mercado global do açúcar.

Impende destacar que a Comunidade Europeia, mesmo com grande superioridade comercial em relação ao Brasil, e co-demandantes, mostrou-se disposta a adequar-se às regras da OMC, antes do início da fase de retaliação.

Tal fato não descaracteriza, por assim dizer, o fato de que os países desenvolvidos se utilizam da sua superioridade em desfavor dos países em 
desenvolvimento. A força econômica permite que os países desenvolvidos protelem as demandas no âmbito da OMC, cumprindo as regras apenas quando não há mais margem para procrastinação. No presente caso houve alteração legislativa, mas os danos causados durante os anos de duração dos subsídios ainda persistem.

\subsection{Implementação da recomendação - Caso do algodão}

A resistência dos Estados Unidos em implementar a recomendação dos relatórios do painel e do Órgão de Apelação decorrentes do caso do algodão demonstra a fragilidade das demandas que envolvem países desenvolvidos e países em desenvolvimento. Os Estados Unidos durante muito tempo não acreditaram que o Brasil poderia retaliá-los, situação que fez com que houvesse dificuldades e desafios na implementação da recomendação, que até a data atual não foi efetivamente realizada.

A resistência começou quando, após o prazo razoável concedido pelo Órgão de Solução de Controvérsias, os Estados Unidos não tinham dado sinais de implantação efetiva da decisão, se bastando a eliminar o programa Step 2. Diante de tal fato, o Brasil solicita a abertura de um painel de revisão com a finalidade de se averiguar os andamentos do cumprimento da decisão pelos Estados Unidos.

Na data de 18 de dezembro de 2007 o painel confirma que os programas americanos continuam causando prejuízos aos produtores e exportadores de algodão brasileiros, instaurando o procedimento arbitral para definir os valores dos prejuízos causados.

Em agosto de 2009 é autorizada a retaliação cruzada pelo Brasil.

De posse dessa decisão, iniciam-se, no âmbito interno, estudos para verificar qual medida restritiva se tornaria mais efetiva e menos prejudicial para a economia brasileira. Porém, mesmo com a possibilidade de retaliação, os Estados Unidos não demonstram vontade em cumprir o determinado. Isso só ocorrerá quando o Brasil der sinais concretos de que, de fato, realizará a retaliação, tal como autorizado pelo Órgão de Solução de Controvérsias. 
Assim, a Câmara de Comércio Exterior (CAMEX) inicia os estudos para proceder com a retaliação dos produtos americanos, incorporado no estudo a retaliação no âmbito de propriedade intelectual (TRIPS) e serviços (GATS).

Na data de 06 de novembro de 2009 é publicada a resolução Camex n $^{\circ}$ 79 , tendo como objeto a instauração de procedimento de consultas públicas relativas à lista preliminar de produtos/serviços a serem retaliados.

Em março de 2010 são expedidas as resoluções contendo as listas definitivas de produtos a serem retaliados. A partir dessa data, os Estados Unidos buscam o Brasil para tentar uma solução pacífica para o conflito. Ou seja, após 08 (oito) anos de contenda, só após o Brasil definir a estratégia para a retaliação cruzada é que os Estados Unidos objetivam por fim ao contencioso, de forma "amigável”.

Assim, após a definição da lista de produtos, os Estados Unidos objetivam a realização de acordo, com a finalidade de evitar a retaliação proposta. $\mathrm{O}$ Brasil aceita negociar.

Dessa maneira, os Estados Unidos propõem a criação de um fundo de US\$ 147 milhões (cento e quarenta e sete milhões de dólares) para apoio aos produtores brasileiros de algodão e a redução parcial das linhas de crédito à exportação, condenadas pela OMC, e, ainda o comprometimento da redução total dos subsídios quando da revisão da Lei Agrícola daquele país, prevista para ocorrer no ano de 2012.

Impende ressaltar que tais medidas dependem da aprovação do Congresso Americano, mas, assim mesmo, o Brasil aceita suspender a retaliação. Como resultado das negociações, é aprovada pelo Congresso Americano a criação do fundo, que visa o repasse de US\$ 147 milhões até que os subsídios sejam suspensos.

Com isso, os Estados Unidos oferta uma compensação financeira ao Brasil e não cumpre com a decisão emanada pela OMC. Ou seja, as práticas ilegais continuam em vigor, causando prejuízos para os países interessados, que não fazem parte do acordo formulado.

O Congresso americano cogitou, em março desse ano de 2011, a suspensão do pagamento do referido valor, porém, a proposta foi derrotada após grande influência dos setores que podem ser afetados pela retaliação. 
O que se conclui é que a criação do fundo não resulta na implementação da decisão. Os Estados Unidos mantém os subsídios considerados ilegais pela Organização Mundial do Comércio. O Brasil aceitou receber compensação financeira até que a legislação seja modificada, porém, está sujeita a suspensão desses pagamentos pela vontade do Congresso Americano. Os setores interessados a evitar a retaliação conseguem exercer pressão para que os pagamentos não sejam suspensos, mas, conseguirão exercer pressão para que a implementação seja de fato efetivada?

Segundo os entendimentos mantidos, os Estados Unidos têm até 2012 para alterar a sua legislação. Será que os entendimentos da OMC serão obedecidos pela grande potência?

\subsection{Do cumprimento das decisões do Órgão de Solução de Controvérsias}

Percebe-se que há grande resistência dos países, especialmente os desenvolvidos, em implantarem as decisões provenientes da OMC. Os países membros da Organização devem se conscientizar que na atual conjuntura internacional há uma grande interdependência entre Estados, seja através do emprego dos regimes internacionais, seja através da utilização dos organismos internacionais, como a OMC.

As normas são de grande relevância para o aprofundamento da interdependência global. Os Estados Nacionais, da forma como atualmente interdependentes, necessitam cumprir a normas das Organizações das quais são signatários para assegurar o aprofundamento das relações internacionais.

Os Estados contemporâneos aceitam as mencionadas normas, no momento em que se comprometem a cumpri-lo através da ratificação de tratados, etc. A própria vontade dos Estados em fazer parte das Organizações Internacionais é uma prova irrefutável de que as normas favorecem a interdependência global.

Ocorre que, mesmo cientes da necessidade de cumprirem as normas internacionais, os Estados se utilizam do seu poderio econômico para se esquivar do seu cumprimento. 
O Sistema de Solução de Controvérsias oferta mecanismos de coerção aos países vencedores da demanda, porém, não há garantias da efetividade das decisões. O problema da implantação das decisões gera, inclusive, críticas ao Sistema de Solução de Controvérsias como um todo.

Porém, não há que se considerar que o Sistema de Solução de Controvérsias é hoje completamente descabido, uma vez que, como visto, há participação dos países em desenvolvimento nos contenciosos, e o órgão apresenta imparcialidade quando da análise das demandas.

Deve-se apenas buscar um meio mais eficaz de controle de implantação das demandas, ressaltando-se que, atualmente, o modelo encontrado apresenta-se favorável no contexto em que foi criado e que é aplicado. Um bom início seria a conscientização dos países desenvolvidos de que o modelo atual não é o ideal. 


\section{CONCLUSÃO}

Com a mudança do comportamento comercial no cenário internacional pode-se observar o surgimento da Organização Mundial do Comércio OMC em substituição ao GATT. A OMC é constituída para acompanhar as mudanças das relações internacionais, uma vez que, no período, com o aumento do número de transações internacionais, se fez necessária a criação de uma organização internacional para estabelecer o regramento necessário.

Assim, na Conferência de Marraqueche, no ano de 1994, 123 países aderem ao acordo que criava a Organização Mundial do Comércio. Apesar das críticas que envolvem a referida Organização, como o fato de se dar mais importância ao regramento das questões que interessam aos países desenvolvidos, como, por exemplo, a questão da propriedade intelectual em detrimento da questão da agricultura, o fato é que a OMC vem para estabelecer um Sistema de Solução de Controvérsias diverso das tentativas anteriores, e que possui fortes mecanismos capazes de forçar os membros a cumprirem as regras estabelecidas.

O Órgão de Solução de Controvérsias é o responsável pelo processamento das demandas, regulador das questões estatuídas no Entendimento de Solução de Controvérsias, documento integrante do Acordo Constitutivo da OMC. O Entendimento de Solução de Controvérsias possui a função de regular os conflitos existentes no âmbito da OMC, bem como assegurar que todos os acordos firmados no âmbito da referida organização internacional sejam cumpridos.

O grande desafio do Sistema de Solução de Controvérsias da OMC consiste na implementação das decisões. Por muitas vezes os países conseguem o reconhecimento de que as regras da Organização não estão sendo cumpridas, porém, não há mudança em tais regras, ou seja, o país demandado continua descumprindo as normas do comércio internacional, sem que nada seja feito.

Porém, o Entendimento de Solução de Controvérsias da OMC possui atributos que ainda não são ideais para assegurar a plena implantação das decisões, mas funcionam como fortes instrumentos de coerção. O instrumento mais poderoso nesse sentido é a autorização para a Retaliação Cruzada. 
Ou seja, o Entendimento de Solução de Controvérsias permite que o membro vencedor, após autorizado pelo Órgão de Solução de Controvérsias, retalie o membro vencido. Essa retaliação deve acontecer no mesmo setor demandando. Porém, se o país conseguir provar que a decisão no mesmo setor não terá efetividade, poderá ser autorizada a retaliação cruzada.

Para os países em desenvolvimento a retaliação no mesmo setor demandada é, na maioria das vezes mais prejudicial para o aplicador da retaliação do que ao país demandado, uma vez que a imposição de barreiras tarifárias ou outras medidas nesse sentido acarretam prejuízos internos de tamanha monta que não compensam a retaliação.

A retaliação cruzada se torna, dessa maneira, a grande arma dos países em desenvolvimento contra os países desenvolvidos, no intuito de compeli-los a cumprir as decisões emanadas do Órgão de Solução de Controvérsias. O instrumento oferece vantagens tendo em vista que os países em desenvolvimento, quando autorizados a usar a referida retaliação, possuem a chance de suspender os direitos de propriedade intelectual e desenvolver produtos a custos baixos, sem terem que observar a regra de marcas e patentes. Há também grande pressão dos setores que protegem a propriedade intelectual para que o cumprimento dos relatórios seja efetivado.

Porém, a retaliação cruzada também oferece desvantagens, uma vez que o país demandante, se não possuir capacidade econômica para realizá-la, por vezes será mais prejudicado do que o membro demandado. Também pode haver conseqüências comerciais internas graves, como prejuízos a importadores e aumento da pirataria, por exemplo.

O Brasil se apresenta como um país ativo no que concerne às demandas do Sistema de Solução de Controvérsias da OMC, já tendo participado de 25 casos como demandante, catorze casos como demandado e 61 como terceira parte.

No presente trabalho foram destacados dois casos relevantes: o do açúcar e o do algodão.

A demanda do açúcar se inicia quando o Brasil, juntamente com a Austrália e a Tailândia contestaram os subsídios concedidos pela Comunidade 
Europeia à produção e exportação do açúcar. Após anos de contencioso o painel, bem como o Órgão de Apelação reconheceram a ilegalidade dos subsídios e recomendaram a modificação dos programas por parte da União Europeia.

A implementação da decisão não foi realizada de maneira corriqueira, uma vez que a Comunidade Europeia tentou protelar, ao máximo, a realização das mudanças legislativas. Porém, acabou por acatar as decisões da OMC e realizou a modificação do seu regramento. Os reflexos da mudança da política do açúcar foram sentidos após as modificações, corroborando que os subsídios ofertados tinham o condão de desestruturar a economia internacional no que toca o mercado do açúcar.

Já a demanda do algodão teve início com a contestação, pelo Brasil, dos programas de subsídios norte-americanos à sua produção de algodão. O caso é considerado um dos mais relevantes já julgados no âmbito da OMC.

Tanto o relatório do painel, quanto do Órgão de Apelação foram favoráveis ao Brasil. Após a adoção dos relatórios, Brasil e Estados Unidos iniciaram outra disputa: a implementação da decisão.

Os Estados Unidos utilizaram todos os artefatos protelatórios possíveis para seguir com não cumprimento as normas da OMC. Somente após o Brasil editar Medida Provisória contendo a lista dos produtos passíveis de retaliação é que os Estados Unidos se mostraram dispostos a fazer um acordo. Vê-se que não houve cumprimento da decisão, ou seja, os subsídios concedidos continuam a produzir efeitos, tendo os Estados Unidos acordado em pagar anualmente valor á título de indenização, até o ano de 2012, data prevista para a mudança na estrutura dos subsídios.

A partir da análise desse caso, e de tantos outros em trâmite no Órgão de Solução de Controvérsias da OMC, observa-se que, apesar da estruturação do Sistema de Solução de Controvérsias, ainda há a prevalência do uso do poderio econômico quando da necessidade de cumprimento das decisões.

Os países desenvolvidos se utilizam da sua vantagem econômica para descumprir as regras da OMC, uma vez que os países em desenvolvimento e os países com menor desenvolvimento relativo não possuem condições de levar adiante as suspensões de concessões, ou melhor, as retaliações autorizadas pela OMC. 
No caso do algodão, pela primeira vez foi concedido o direito de retaliação cruzada a um país em desenvolvimento com condições de proceder, de fato, com a retaliação. E, somente após o Brasil tomar medidas no sentido de que iria retaliar os Estados Unidos é que houve indicações de que a decisão poderia, um dia, ser implementada. Assim mesmo não houve a retaliação efetiva.

Dessa maneira, deve-se ressaltar, como visto ao longo do presente trabalho, que o Sistema de Solução de Controvérsias apresenta anomalias que tocam a implantação das suas decisões, com favorecimento dos países desenvolvidos. Porém, há que se dizer que o Sistema é, atualmente, a melhor forma de se regrar o comércio internacional. Anomalias existem em todos os sistemas, e no plano internacional não haveria de ser diferente. Existem forças políticas envolvidas que não serão brevemente suplantadas.

Não há que se dizer que o Sistema de Solução de Controvérsias é hoje completamente descabido, porque há participação dos países em desenvolvimento nos contenciosos, e o órgão apresenta imparcialidade quando da análise das demandas. Deve-se apenas buscar um meio mais eficaz de controle de implantação das demandas, ressaltando-se que, atualmente, o modelo encontrado apresenta-se favorável no contexto em que foi criado e que é aplicado.

Os Estados Membros da OMC devem se conscientizar de que a estrutura internacional torna os países, de certa forma, interdependentes, pelo que necessitam cumprir a normas das Organizações das quais são signatários para assegurar o aprofundamento das relações internacionais.

A atitude dos países que negam o cumprimento de uma decisão emanada de Organização Internacional de que são membros deve ser condenada por todos os Membros, e não deve ser a regra. Como de fato, não é. A evolução das relações internacionais acabará por provar a necessidade de cumprimento dessas decisões, para o bom funcionamento das Organizações Internacionais.

Espera-se, assim, que o rumo das relações internacionais se altere, mais uma vez, tal como quando da necessidade da substituição do GATT para a OMC, e que os países se dêem conta de que uma maior proteção internacional aos países em desenvolvimento e aos países de menor desenvolvimento relativo é 
condição para o fortalecimento do comércio internacional e desenvolvimento de todos.

A efetividade do Sistema de Solução de Controvérsias depende da mudança de posição dos países desenvolvidos em aceitarem discutir as mudanças nas regras do Entendimento de Solução de Controvérsias. 


\section{REFERENCIAS}

\section{Livros}

ARAÚJO, Leandro R. e outros. Agricultura e Subsídios: o “Caso do Algodão”. In LIMA, Maria Lúcia L.M. \& ROSERNBERG, Barbara. (Orgs.) Solução de Controvérsias: O Brasil e o Contencioso na OMC: Tomo I. São Paulo: Saraiva, 2009.

AQUINO, Christiane e outros. O Contencioso entre Brasil e Comunidades Europeias sobre os Subsídios ao Açúcar (DS 266). In LIMA, Maria Lúcia L.M. \& ROSERNBERG, Barbara. (Orgs.) Solução de Controvérsias: O Brasil e o Contencioso na OMC: Tomo I. São Paulo: Saraiva, 2009.

BARRAL, Welber. O Comércio Internacional. Belo Horizonte: Del Rey Editora, 2007.

BARRAL, Welber, organizador. Solução de Controvérsias na Organização Mundial do Comércio. Brasília: Ministério das Relações Exteriores: Fundação Alexandre Gusmão, 2007.

CASSEB, Paulo Adib. Federalismo: Aspectos contemporâneos. São Paulo: Juarez de Oliveira, 1999

GONÇALVES, Reinaldo. O Brasil e o Comércio Internacional: Transformações e Perspectivas. 2 ed. São Paulo: Contexto, 2003

HABERMAS, Jürgen. A inclusão do outro. Edições Loyola: São Paulo, 2002.

LIMA, Ieda Miyuki Dias de. Síntese dos Contenciosos do Brasil no OSC da OMC. In LIMA, Maria Lúcia L.M. \& ROSERNBERG, Barbara. (Orgs.) Solução de Controvérsias: O Brasil e o Contencioso na OMC: Tomo II. São Paulo: Saraiva, 2009.

LIMA, Maria Lúcia L.M. \& ROSERNBERG, Barbara. (Orgs.) Solução de Controvérsias: O Brasil e o Contencioso na OMC: Tomo I. São Paulo: Saraiva, 2009.

LIMA, Maria Lúcia L.M. \& ROSERNBERG, Barbara. (Orgs.) Solução de Controvérsias: O Brasil e o Contencioso na OMC: Tomo II. São Paulo: Saraiva, 2009. 
JACKSON, John H., The Jurisprudence of GATT \& The WTO. Insights on Treaty Law and Economic Relations. Cambridge: Cambridge University Press, 2000.

JAWARA, F. and A. Kwa (2004), Behind the Scenes at the WTO: The Real World of International Trade Negotiations/Lessons from Cancun, updated edn, London: Zed Books.

JOB, Ulisses da Silveira. OMC Multilateralismo e Desenvolvimento. Curitiba: Juruá, 2011.

JUNQUEIRA, Carla. In LIMA, Maria Lúcia L.M. \& ROSERNBERG, Barbara. (Orgs.) Solução de Controvérsias: O Brasil e o Contencioso na OMC: Tomo II. São Paulo: Saraiva, 2009.

PINHEIRO, Silvia Marina. Responsabilidade Internacional dos Estados na OMC. São Paulo: Aduaneiras, 2007.

REIS, Márcio Monteiro. Mercosul, União Européia e Constituição. Rio de Janeiro: Renovar, 2001.

SATO, Eiiti. De GATT para OMC e a Agenda do Brasil no Comércio Internacional. In: ALTEMANI, Henrique \& LESSA, Antônio Carlos (Orgs.). Relações Internacionais do Brasil: Temas e agendas. Volume 2. São Paulo: Ed. Saraiva, 2006, p.125/155

SILVA, Volney Zamenhof de Oliveira. Elementos de Teoria Geral do Estado Comunitário. Campinas: Interlex, 2000.

THORSTENSEN, Vera. OMC - Organização Mundial do Comércio: as regras do comércio internacional e a rodada do milênio. São Paulo: Aduaneira, 1999.

\section{Internet}

AMARAL, Renata Vargas. O Distinto Nível de Desenvolvimento dos Países e sua Influência na Falta de Eficácia dos Mecanismos de Execução de Decisões da OMC. Revista dos Tribunais. Volume 872. Disponível na internet: <www.revistasrtonline.com.br > . Acesso em 10.02.2011.

SILVA, Cláudio Ferreira da. Do Gatt À Omc: O que mudou, como funciona e perpectivas para o Sistema Multilateral De Comércio. Disponível em < 
http://www.publicacoesacademicas.uniceub.br/index.php/relacoesinternacionais/artic le/viewFile/297/264>. Acesso em 10.02.2011

TORRES, Edgard Marcelo Rocha. O caso dos subsídios do algodão entre Brasil e EUA. O uso efetivo da retaliação cruzada como prova final da eficácia do sistema de solução de controvérsias da OMC: redenção ou ruína?. Jus Navigandi, Teresina, ano 15, n. 2521, 27 maio 2010. Disponível em: <http://jus.uol.com.br/revista/texto/14927>. Acesso em: 1 abr. 2011.

\section{Sites pesquisados}

Sítio da Organização Mundial do Comércio: http://www.wto.org/

Sítio do Ministério do Desenvolvimento, Indústria e Comércio: http://www.mdic.gov.br//sitio/

Sítio do Ministério das Relação Exteriores: http://www.itamaraty.gov.br/ 